\title{
Competitiveness of Travel and Tourism in Selected Countries
}

\author{
Elena Širá1 / Ryszard Pukała ${ }^{2}$ \\ e-mail: elena.sira@unipo.sk, ryzsard.pukala@interia.pl
}

${ }^{1}$ Department of Economy and Economics, Faculty of Management, University of Prešov, Prešov, Slovakia ${ }^{2}$ Department of Economics and Management, State Higher School of Technology and Economics in Jarosław, Jarosław, Poland

Širá, E., \& Pukała, R. (2019). Competitiveness of Travel and Tourism in Selected Countries. Czech Journal of Tourism, 8(1), 17-31. DOI: 10.2478/cjot-2019-0002.

\begin{abstract}
Competitiveness of the country is a very important factor, especially in the area of tourism. Tourism is one of the most important and most rapidly growing economy sectors, which faces the challenges and possibilities of globalization. The travel and tourism sector is widely recognized as an important factor for the regional development. This enables the country to be successful in the world market and for tourists. To measure the competitiveness of travel and tourism, we used various indexes. One of them is the Travel \& Tourism Competitiveness Index, published by the World Economic Forum. The aim of this paper is to analyse the travel and tourism competitiveness in selected countries. According to their performance, we identified the best travel and tourism country. In addition, we focused on strengths and weaknesses of the analysed countries to improve their competitiveness position in the future.
\end{abstract}

\section{Keywords}

Travel \& Tourism Competitiveness Index, World Economic Forum, competitiveness, country evaluation

JEL classification: Z32, O40 


\section{Introduction}

Modern tourism arose during the industrial revolution in the late $19^{\text {th }}$ and early $20^{\text {th }}$ century as a result of productive forces development. As the object of knowledge, tourism began to be systematically examined in the $20^{\text {th }}$ century and proved to be interdisciplinary. The various academic disciplines always investigate tourism from their point of view and by their methodological approach, but the knowledge of one discipline influences others (Šenková et al., 2015).

A global perspective to understand the key determinants of the market competitiveness is critical for the tourism industry to sustain its growth and vitality. Today's tourism markets cannot be characterized as homogeneous. Trends in consumer traveller demand have dramatic impacts on the tourism industry, especially in an overly segmented global marketplace. The emergence of niche and specialty tourism segments on a transnational basis has changed the way in which destinations develop their appeal and sustain their competitive positions (Hassan, 2000). Tourism is embodied by free rides and its performance largely depends on the success of other industries (Kubickova, 2016).

For this reason, it is necessary, especially in tourism, to know the competitive position of the region. This article focuses on identifying and comparing the competitiveness of tourism, both on a theoretical basis and practical examples of the selected countries.

\section{Theoretical basis}

\section{Competitiveness}

According to Vida, Kadár, and Kadárová (2017), there is no homogeneous definition of the term competitiveness in the economic literature. Different characteristics of competitiveness result from several dimensions of the term and can be distinguished at the basic levels of competitiveness, specifically the region, state, industry, enterprise, and product.

Djogo and Stanisic (2016) compare the OECD's definition of macro-competitiveness, which says that macro-competitiveness is the country's ability to produce goods and services on fair market conditions that could raise of citizens' real income. They also state a very similar definition of the European Commission (Kravcakova-Vozarova et. al., 2015), which defines macro-competitiveness as the ability of economy to provide its inhabitants with a high and growing standard of living, as well as a high employment rate on a sustainable basis.

According to Liu (2017), literature has identified two broad categories of determinants of international competitiveness, specifically macroeconomic conditions and microeconomic strategies. The macroeconomic conditions form a context that creates opportunities for competitiveness at national, regional and cluster level and creates conditions for competitiveness at a company level. The macroeconomic determinants include factors such as institutions (e.g., rules and regulations), economic and financial policies and developments, physical infrastructure and geographical factors. The microeconomic strategies have a direct impact on the firm's competitiveness and include factors such 
as the sophistication of the company's business strategies and its interaction with other companies (Liu, 2017).

Through many countries and sectoral studies, Michael Porter points out that competitiveness is no longer just a function of macroeconomic reforms, but also of microeconomic changes. He found that although no resource value contributed to industry's competitiveness, marketing strategies, innovation, and relationships with the supply and user industries are becoming competitive (Ajitabh, 2008).

\section{Competitiveness of Tourism}

Tourism is one of the most important and most rapidly growing economy sectors, which faces the challenges and possibilities of globalization. Tourism development has great importance and plays a significant role in the development of national economies (Karahuta et al., 2017). The empirical research analysing the relationship between the tourism activity and the economic growth has been flourishing since 1970s. The travel and tourism sector is widely recognized as an important factor for the regional development, which has a potential to contribute to the development of national and regional economies (Lušticky \& Musil, 2016). According to the statistics of the UNWTO, this is a sector with significant economic benefits (Hvizdová, 2017).

Tourism is to be considered a greatly important part of urban development as it combines a competitive supply of tourism services, which corresponds to the expectations of tourists, and a positive impact on the development of regions and cities. Cultural potential of regions or individual localities is an important factor of their economic development and competitiveness (Tej \& Matušikova, 2014).

The competitiveness of tourist destinations becomes increasingly important to the countries that intend to control a large share of rapidly growing tourism market. This is particularly important to the tourism-dependant countries, which heavily rely on tourism and travel industry. The identification and evaluation of tourism competitiveness factors is a common research problem of many research studies and articles on tourism economics (Navickas \& Malakauskaite, 2009). The following authors contributed to the analysis of tourism sector and tourist destination competitiveness: Palatková and Hrubcová (2015), Widawski (2017), Hvizdová (2018).

The attractiveness of a destination reflects the feelings and opinions of its visitors about the destination's perceived ability to satisfy their needs. The more the destination is able to meet the needs of the tourists, the more it is perceived to be attractive and the more the destination is likely to be chosen (Vengesayi, 2013).

Understanding the country competitiveness in tourism is a major consideration for policy makers and a major challenge for professionals in providing evidence to inform decision-making. Various indicators have been developed by different organisations over the years to address specific aspects of competitiveness (Dupeyras \& MacCallum, 2013).

Competitiveness and attractiveness view destinations from two different perspectives (Buhalis, 2001); one from the tourist perspective, i.e. attractiveness (Šambronská et al., 2016), and the other from the destination perspective, i.e. competitiveness. Dual 
analyses of these two concepts provide a holistic perspective of the Tourist Destination Competitiveness and Attractiveness (TDCA) dynamics. TDCA is defined as an ability of a destination to provide social, physical and economic benefits to the destination population, as well as a satisfying experience to the tourist (Vengesayi, 2013).

The influences on competitiveness can change quickly and this dynamics creates further challenges and a need for on-going research and development on indicators. Global economic and tourism trends, including changing market trends and travel behaviours, the role of social media and new sources of demand and growth increase the importance of the topic and the ability of the countries to compete within the changing global marketplace (Dupeyras \& MacCallum, 2013). According to the authors, tourism competitiveness is about the ability of the place to optimise its attractiveness for residents and non-residents, to deliver quality, innovative, and attractive tourism services to consumers and to gain market shares on the domestic and global market places, while ensuring that the available resources supporting tourism are used efficiently and in a sustainable way.

As a result, the key indicators have been developed to address common challenges in the analysis of competitiveness in tourism in member and partner countries. The indicators are organised according to four categories (Dupeyras \& MacCallum, 2013):

- Indicators measuring the tourism performance and impacts;

- Indicators monitoring the ability of a destination to deliver quality and competitive tourism services;

- Indicators monitoring the attractiveness of a destination;

- Indicators describing policy responses and economic opportunities.

The measurement framework comprises three types of indicators that can be applied to measure competitiveness in tourism - core, supplementary and for future development. The 11 core indicators are as follows (Dupeyras \& MacCallum, 2013):

1. Tourism Direct Gross Domestic Product - a comparison of TDGDP change over years is the key statistics of tourism competitiveness and will reinforce use of the TSA. The focus is on direct impacts, domestic and inbound tourism consumption. The challenge for the future is measuring the indirect and induced impacts. A comparison of TDGDP change over years is perhaps the only, most quotable statistics of tourism competitiveness.

2. Inbound tourism revenues per visitor by source market - a measure of the economic activity of visitors identifying the percentage growth or decline year-on-year in inbound tourism revenues per visitor by source market. The focus is on the inbound tourism consumption. The challenge is data availability and consistent protocols.

3. Overnights in all types of accommodation - a measure of tourism flows in accommodation, describing the percentage growth or decline year-on-year in overnights in all types of accommodation or, if not available, in hotels and similar establishments. The focus is on the inbound and domestic (internal) tourism economy. The challenge is measuring unregistered and private accommodation. 
4. Exports of tourism services - a measure of exports of tourism services and relative performance compared with other sectors, describing the growth or decline year-onyear in value and in percentage. The focus is on the inbound tourism consumption. The challenge is to collect detailed data for sub-segments. The measure will show a change in performance reflecting the competition in terms of brand, value awareness and international appeal.

5. Labour productivity in tourism services - a measure of the level and evolution of productivity of those employed in tourism and the productive potential of the tourism economy shown in a table of productivity measures and growth rates per country. Productivity is the main dimension of competitiveness. The challenge relates to difficulties of measurement, particularly quality issues, and the specificity of the tourism sector including the small businesses.

6. Purchasing Power Parity (PPPs) and tourism prices - a measure of tourism price level differences across countries expressed as indices with a basis (real or artificial) chosen by a country or a country group. Changing costs are among the most important competitiveness factors. The challenge is to develop detailed tourism sector specific item groups and prices for individual items.

7. Country entry visa requirements - a measure of entry visa requirements including the methods of visa issuance and a number of visas issued per year and the share of the inbound tourism arrivals. Traveller mobility is a critical element and the visa issues are part of the competitiveness environment. The challenge is to find a suitable format for the policy analysis given that visa policies vary considerably across countries.

8. Natural resources and biodiversity - a measure of a country's stock of natural assets, in terms of the number of acknowledged natural heritage sites and preserved areas. This should be assessed alongside with the information on biodiversity and ecosystems, geographic location and population density. The natural resources are the key drivers of attractiveness and offer countries a competitive advantage. The challenge is to identify a consolidated measure.

9. Cultural and creative resources - a composite measure of the number of acknowledged cultural and creative attractions in different forms. The cultural and creative resources are the key drivers of attractiveness. Building a strategy that capitalises on the cultural and creative resources can provide competitive advantages. The challenge is to identify a consolidated measure.

10. Visitor satisfaction - a measure of the demand side attractiveness value, using a comparable measure of visitor satisfaction rating and intention for repeat visits. The visitor satisfaction is an important qualitative indicator from the demand side. The challenge is to collect data, which are based on solid statistical methods and allow a comparison over time.

11. National Tourism Action Plan - a competitiveness eligibility indicator that considers the existence and quality of implementation, effectiveness and evaluation of the National Tourism Action Plan to improve the competitiveness of tourism in a country. The challenge is to see how best to describe the value of the action plan to improve the competitiveness of a destination. 


\section{Travel \& Tourism Competitiveness Index}

The first Travel \& Tourism Competitiveness Index (TTCI), developed in 2007, measures a set of factors and policies that enable a sustainable development of the Travel \& Tourism sector, which, in turn, contributes to the development and competitiveness of a country. The index has been developed in the context of the World Economic Forum's Industry Programme for Aviation, Travel and Tourism, and in close collaboration with our other partners.

The Report, which analyses the performance of 136 economies through the Travel \& Tourism Competitiveness Index (TTCI), provides a unique insight into the strengths and areas for the development of each country to enhance its industry competitiveness. It allows for a cross-country comparison, for benchmarking countries' policy progress and for making investment decisions related to the business and industry development.

The World Economic Forum has, for the past 11 years, engaged the key industry of tourism and sought leaders through its Aviation \& Travel Industry Partner Community to carry out an in-depth analysis of the Travel and Tourism (T\&T) competitiveness of economies around the world. The resulting Travel \& Tourism Competitiveness Report provides a platform for a multi stakeholder dialogue with the objective of achieving a strong and sustainable T\&T industry capable of contributing effectively to the international economic development (World Economic Forum, 2017).

The T\&T Competitiveness Index measures four broad factors of competitiveness. These factors are organized into sub-indexes, which are further divided into 14 pillars (Figure 1 below).

Figure 1 Travel \& Tourism Competitiveness Index

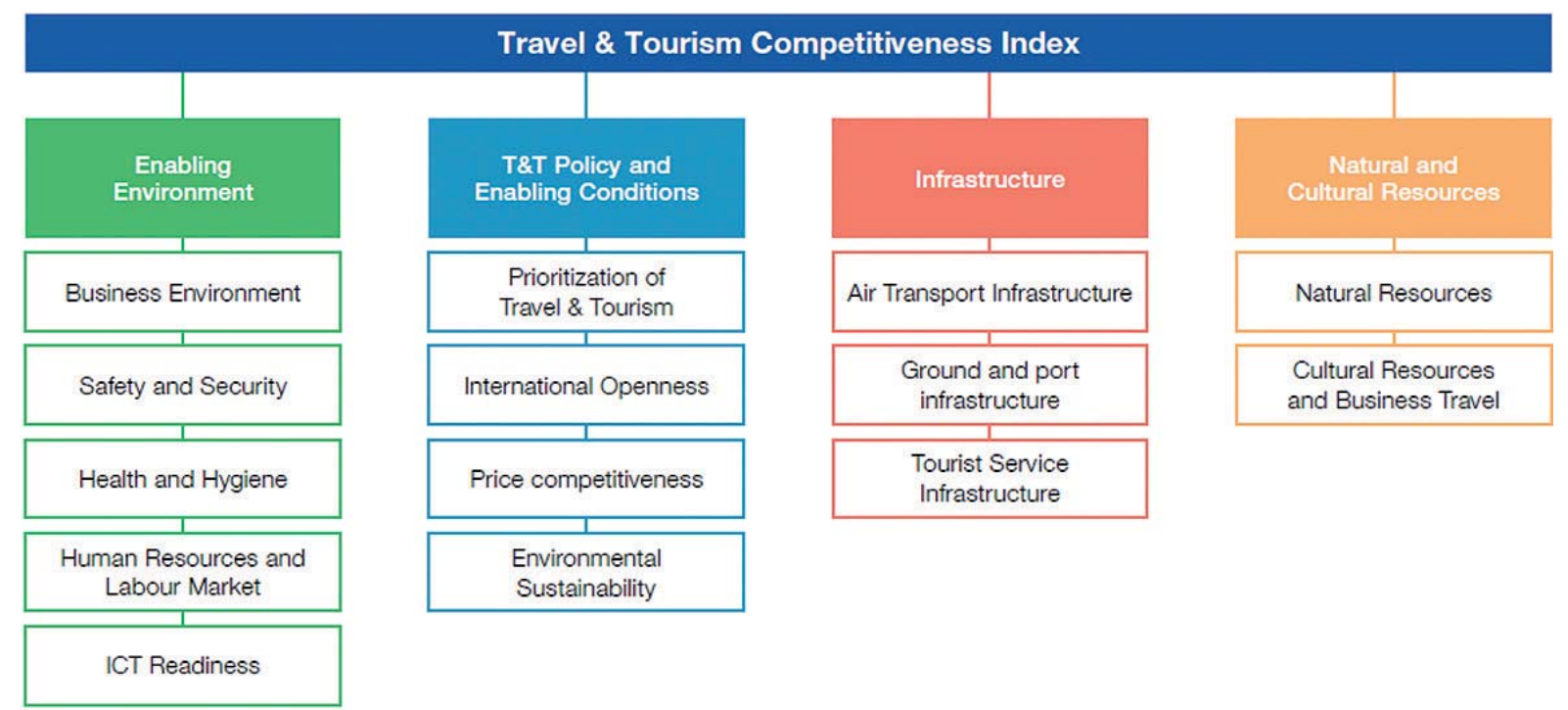

Source: World Economic Forum (2017) 
The T\&T Competitiveness Index measures four broad factors of competitiveness. These factors are organized into sub-indexes, which are further divided into 14 pillars:

The Enabling Environment sub-index, which describes the general settings, necessary for operating in a country:
1. Business Environment
2. Safety and Security
3. Health and Hygiene
4. Human Resources and Labour Market
5. ICT Readiness

The T\&T Policy and Enabling Conditions sub-index, which depicts specific policies or strategic aspects that impact the T\&T industry more directly:

1. Prioritization of Travel and Tourism

2. International Openness

3. Price Competitiveness

4. Environmental Sustainability

The Infrastructure sub-index, which captures the availability and quality of physical infrastructure of each economy:

1. Air Transport Infrastructure

2. Ground and Port Infrastructure

3. Tourist Service Infrastructure

The Natural and Cultural Resources sub-index, which describes the principal 'reasons to travel':

1. Natural Resources

2. Cultural Resources and Business Travel (World Economic Forum, 2017)

Four key findings emerge from the results of the 2017 TTCI in combination with other quantitative and qualitative analysis:

1. First, the T\&T competitiveness is improving, especially in developing countries, and particularly in the Asia-Pacific region. As the industry continues to grow, an increasing share of international visitors are coming from and travel to emerging and developing nations.

2. Second, in an increasingly protectionist context-one that hinders the global tradethe T\&T industry continues building bridges rather than walls among people, as made apparent by increasing numbers of people travelling across the borders and global trends towards adopting less restrictive visa policies. 
3. Third, in light of the Fourth Industrial Revolution, connectivity has increasingly become a must-have for countries as they develop their digital strategy.

4. Finally, despite the growing awareness of the importance of the environment, the T\&T sector faces the difficulties to develop sustainably as natural degradation proceeds on a number of fronts (World Economic Forum, 2017).

\section{Destination competitiveness}

Tourist destinations and regions compete with each other for various tourist segments. However, no two destinations are matched or develop at the same rate. Some destinations have an abundance of inherited, natural resources, where others may have limited created assets, such as poor tourism-related infrastructure or other facilitating resources (Wilde \& Cox, 2008). The destination competitiveness is achieved when destinations are able to guarantee a quality tourism experience for visitors and quality of life for residents (Mira et al., 2016).

The destination competitiveness can be evaluated both quantitatively and qualitatively. The quantitative performance of a destination can be measured by looking at such data as tourist arrivals and tourism incomes (hard data). However, there is also a need to take into account the relative qualitative aspects of the destination competitiveness (soft data), as these ultimately drive the quantitative performance. Dimensions contributing to qualitative competitiveness include those attributes or items, which holidaymakers liked best or most disliked during their vacation in the destination (Kozak \& Rimmington, 1998).

The conditions facilitating the destination competitiveness are associated with the characterisation of resources, making a distinction between the inherited, created and support resources, destination management and the cyclical conditions (Mira et al., 2016).

Ritchie and Crouch (2010) present five components which influence the competitiveness of destinations, specifically, the global environment, the competitive framework and planning and development policies (at macro level); and basic resources, attractions, and support resources (at micro level). The previous dimensions influence the destination management and the quality of determining factors. The first combine the factors related to economy, technology, ecology, political, legal, social and cultural conditions, as well as demographic evolution. The second focuses on the relationship with suppliers and customers, for which promotion and dissemination channels take on a particularly relevant role in the stimulation of competition between the destinations that offer similar products, boosting the development of relationships between the tourism organisations, both competitive and collaborative. 
Figure 2 Ritchie and Crouch's model of the destination management

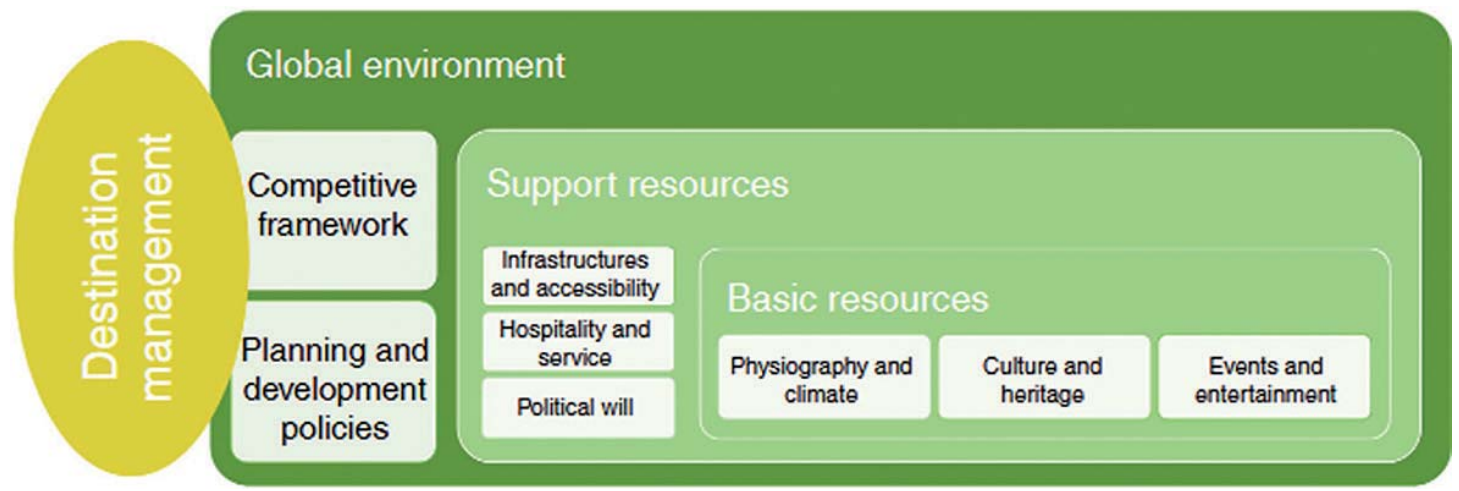

Source: Ritchie and Crouch (2010)

\section{Methodology}

\section{Aim and methods}

Competitiveness is very important for this industry because destinations with a competitiveness advantage and good promotion are more successful than the others. Therefore, we try to identify the competitiveness advantages in tourism in various countries.

The aim of this paper is to identify the best travel and tourism country from the selected countries. According to the analyses and comparison of the travel and tourism (T\&T) competitiveness in the selected countries and their performance, we also focused on strengths and weaknesses of the analysed countries to improve their competitiveness position in the future.

There are many institutions that evaluate the competitiveness. We have chosen the World Economic Forum. This institution has bi-annually published the Travel \& Tourism Competitiveness Index (TTCI) since 2007. This index consists of a set of 11 indicators. These indicators describe the travel and tourism areas that are important for tourism development.

We have focused on the overall performance of the countries and have analysed the score gained in the above mentioned index. The achieved score was in the range of $0-7$ points, where 7 points are the best.

\section{Country and period selection}

We have chosen four European countries for the analyses. The countries were selected according to the values of Travel and tourism indicator on GDP in 2011. All analysed countries from Europe obtained values in the range of $1.5-1.8 \%$. They are as follows:

- Western Europe group: the Czech Republic, Ireland;

- Balkans and Eastern Europe group: Poland, the Slovak Republic. 
TTCI have divided countries into several groups. We have chosen 4 countries from 2 groups. The Czech Republic and Ireland were in Western Europe group and Poland and the Slovak Republic were in the Balkans and Eastern Europe group according to the group selection in TTCI 2017.

We have chosen two mainland countries (one of each group) and 2 seaside countries. The seaside countries were chosen according to their geographical location and climate.

The set period was 9 years. According to the Travel \& Tourism Competitiveness Index, we have analysed the reports for the period of TTCI 2009-2017, because the last published report was TTCI of 2017.

\section{Results}

The tourism sector is among the most dynamically developing industries with the direct impact on economy, industry, trade and services. Tourism is very important for every country, especially when country has unique culture, nature or geology. The most valued cultural monuments of the country are on the list of UNESCO and are characterized by universal value whose preservation is of utmost importance for the future of humanity (Hvizdová \& Radvanská, 2014).

When we analysed the share of tourism on GDP in the selected countries, we could see the low values of this indicator. In all analysed countries, the share on GDP was about $2 \%$. In the course of the years 2011-2017, the development was rising up to year 2015 with a decrease in the values in 2017 in the Czech Republic and Poland. Ireland's value was almost the same. Only the Slovak Republic proved a growing tendency through the whole period. Slovakia is a mountainous country. Forests and mountains cover half of the country area. These natural conditions predetermine a high natural potential for the regional development (Mura \& Ključnikov, 2018).

Table 1 Travel and Tourism on GDP in \%

\begin{tabular}{|l|c|c|c|c|}
\hline & T\&T 2011 & T\&T 2013 & T\&T 2015 & T\&T 2017 \\
\hline Czech Republic & 1.8 & 2.7 & 2.9 & 2.5 \\
\hline Ireland & 1.7 & 2.0 & 2.2 & 2.2 \\
\hline Poland & 1.6 & 1.8 & 2.1 & 1.7 \\
\hline Slovak Republic & 1.5 & 2.3 & 2.3 & 2.4 \\
\hline
\end{tabular}

Source: own processing

Overall, TTCI consists of 11 indicators. The overall performance of this index is illustrated in Figure 3. All analyzed countries recorded a decline in the values of the index in 2015. Even in the next year of 2017, they were unable to reach the values dating back to 2015 . 
The highest TTCI values were achieved during the examined period in Ireland. This country had an average TTCI of 4.812 points during the reporting period, the highest among the rated countries.

According to TTCI, Slovakia is the least competitive country for tourism. According to the chart, we can see that since 2011 we have reached the lowest index values, as evidenced by the lowest average TTCI of 4.148 points.

Figure 3 The development of TTCl score in V4

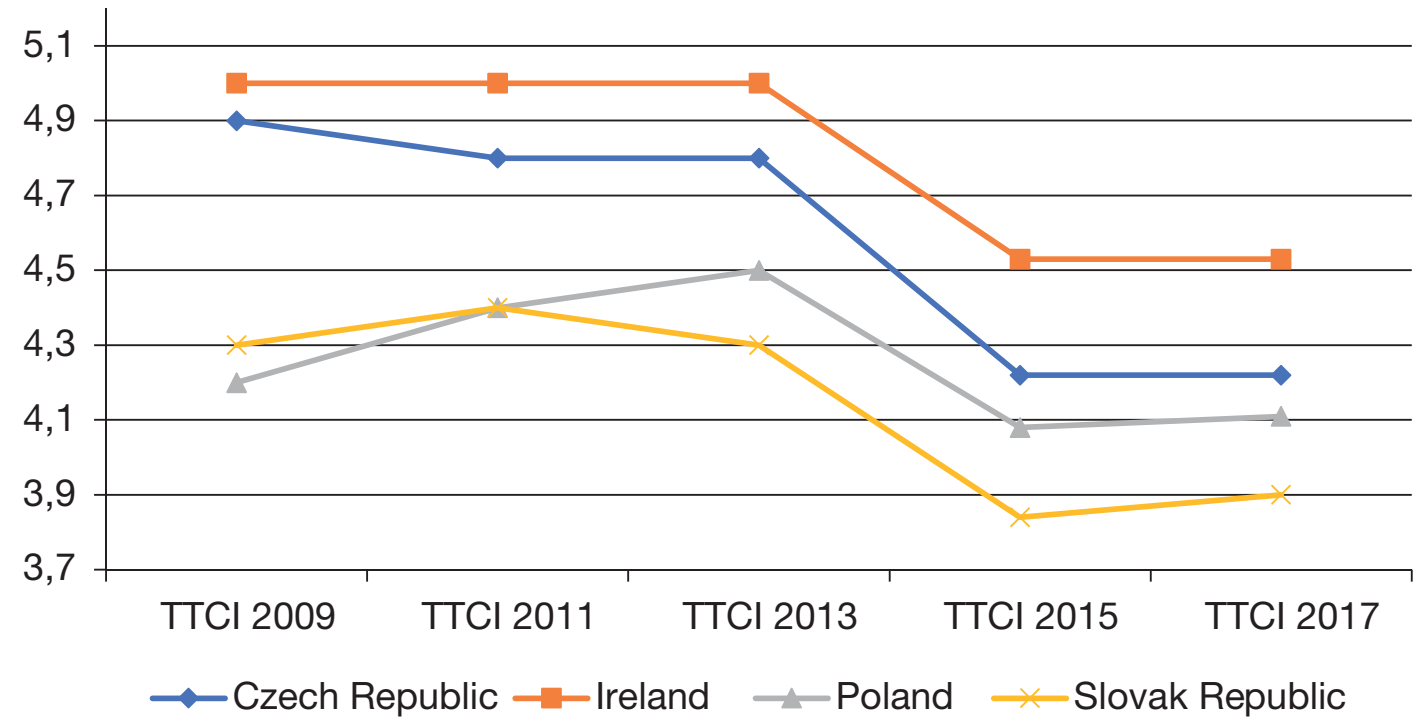

Source: own processing

In order to find out the strong and weak areas of tourism in the countries under review, we have analyzed the latest TTCI 2017 evaluation in detail. This index was divided into 11 indicators and then they were compared to show how countries performed in 2017. For better comparability of the countries, we calculated even the average value for each indicator. The graphic representation is shown in Figure 4 below.

The highest values achieved in all analyzed countries were achieved in the indicator called 'Health and Hygiene'. On the contrary, the lowest values, and thus the most problematic area of tourism in all countries surveyed, was the indicator marked 'Cultural Resources and Business Travel'.

In the Czech Republic, the strongest indicators of tourism competition include 'Safety and Security' and 'Health and Hygiene'. The areas where this country had the greatest problems in 2017 were 'Cultural Resources and Business Travel' and 'Natural Resources'. In both of these indicators, the Czech Republic achieved values below the average level among the countries surveyed.

Ireland has reached the indicators with higher values than the average. The most competitive areas are 'Safety and Security', 'Tourist Service Infrastructure', 'ICT Readinesses', and 'Health and Hygiene'. The areas where this country had the biggest problems in 2017 were, similarly to the Czech Republic, 'Cultural Resources and Business Travel', and 'Natural Resources'. 
Figure 4 The score of $\mathrm{TTCl} 2017$ indicators

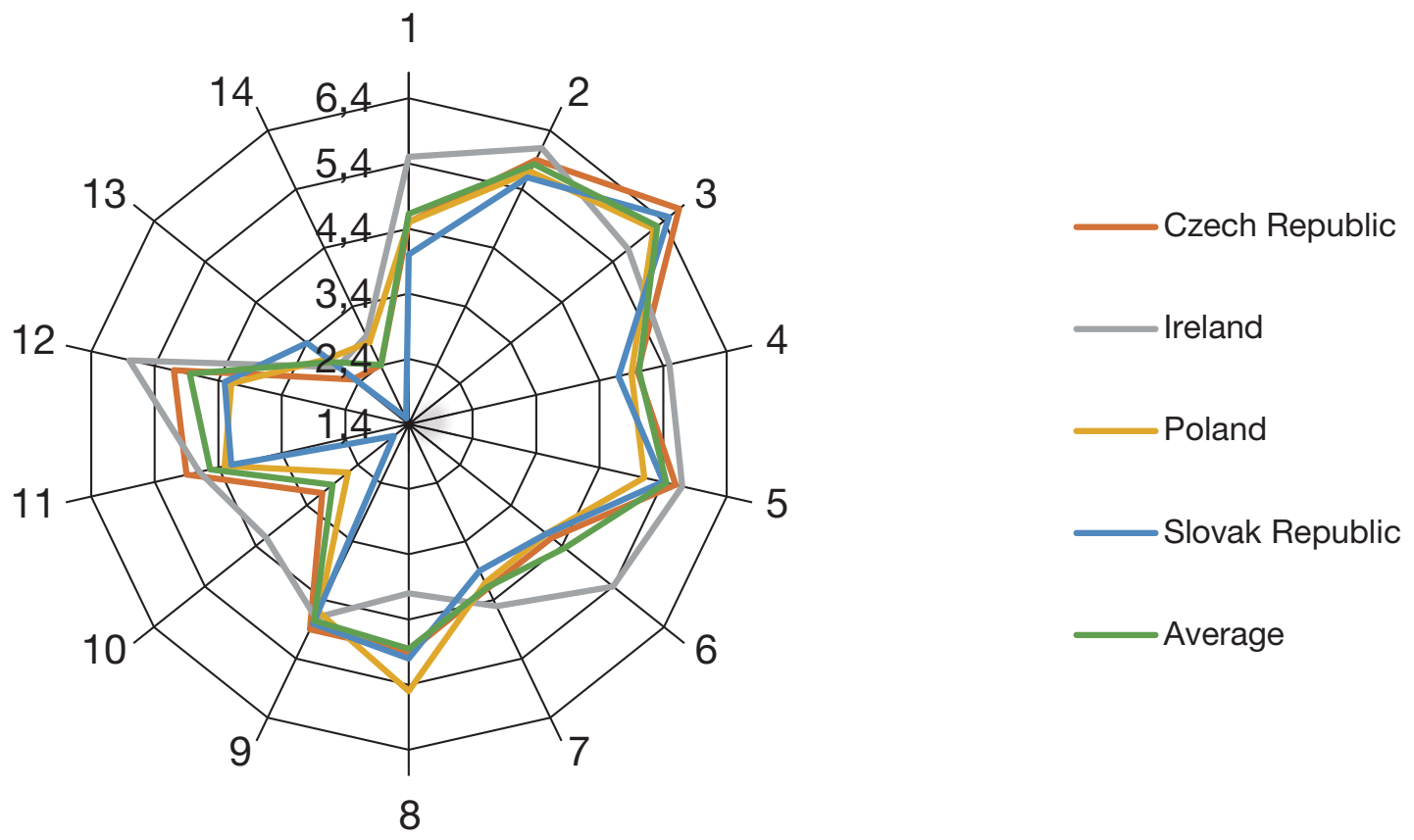

Source: own processing

Explanatory Notes: 1 Business Environment; 2 Safety and Security; 3 Health and Hygiene; 4 HR and Labour Market; 5 ICT Readiness; 6 Prioritization of T\&T; 7 International Openness; 8 Price Competitiveness; 9 Environmental Sustainability; 10 Air Transport Infrastructure; 11 Ground and Port Infrastructure; 12 Tourist Service Infrastructure; 13 Natural Resources; 14 Cultural Resources and Business Travel

The most powerful aspects of Poland were 'Safety and Security' and 'Health and Hygiene' in TTCI 2017. The most questionable and therefore the lowest rating of the country was the indicator 'Cultural Resources and Business Travel'.

Slovakia has also achieved the highest rating in the 'Health and Hygiene' indicator. Here achieved points are comparable to other countries. However, the lowest values were in the weakest indicators, which were significantly lower than in the other countries. The problem areas of Slovakia were 'Cultural Resources and Business Travel' and 'Air Transport Infrastructure' in 2017.

\section{Conclusion}

Tourism is among the most dynamically developing industries with the new, global challenges ahead. It is beneficial to monitor the competitiveness of different countries and to learn from the more successful ones. Every country should know its strengths and weaknesses in order to be able to improve its competitiveness and follow new trends in the area of travel and tourism.

The competitiveness of the country is a very important factor, especially in the area of tourism. This enables the country to be successful in the world market and for tour- 
ists. The competitiveness of tourist destinations becomes increasingly important to the countries that intend to control a large share of rapidly growing tourism market. That is particularly important to the tourism-dependant countries. The influences on the competitiveness can change quickly and this dynamics creates further challenges.

There are many institutions that evaluate the competitiveness. We have chosen the World Economic Forum. This institution bi-annually publishes the Travel \& Tourism Competitiveness Index. We elaborated an analysis of 4 countries where we compared and evaluated the countries in the field of tourism on the basis of the development of Travel \& Tourism Competitiveness Index for the years of 2009-2017. All analyzed countries recorded a decline in the values of the index in 2015. Even in the next year of 2017, they were unable to reach values dating back to 2015. The highest TTCI values were achieved during the examined period in Ireland, the lowest values were achieved in the Slovak Republic.

Subsequently, we focused more closely on the latest (TTCI 2017) rating, and we identified the strengths and the weaknesses in each country. The lowest values, and thus the most problematic area of tourism in all countries surveyed, was the indicator marked 'Cultural Resources and Business Travel'. This indicator did not get the lowest values because of the lack in offer for the tourist in the countries. On the contrary, there are many attractions in the analyzed countries that can attract tourists. But the problem is elsewhere. The entrepreneur's success predetermines the ability to make changes to the entrepreneur competitive advantage that is motivated by the choice of product and supplier customers to the preferences of those who offer this competitive advantage. Carriers of the competitive advantages are innovations, which are changes that bring increased utility and added value. Moreover, the analysed countries do not apply innovations in practice.

Another possible failure in this area is a lack of co-operation between individual subjects of tourism. The question is whether creating a tourism cluster would not be a good choice to solve this problem. Otherwise, to solve the problem of co-operation between the individual subjects of tourism is not in our options. We would have to know how to influence the behavior of people, their habits and opinions. However, these areas are already the subject of further investigation, maybe in cooperation with psychologists.

The indicator called 'Health and Hygiene' was the main strength in all analyzed countries. It is a very good message for tourism. Because when travelers feels good in a foreign country and health care and cleanliness are at high level, it is the first prerequisite for the proper management and promotion of tourists to visit the country. How to address or stimulate travelers to visit the country, are already the subject of further investigation.

Ireland was a country that not only in the Travel \& Tourism Competitiveness Index 2017, but also in all examined period achieved the best results. However, it has to be emphasized that from the TTCI point of view, all four countries were at approximately the same level. Therefore, it is very difficult to determine exactly which European country was the best Travel and Tourism country. However, Ireland achieved the best results in majority of data. 
Tourism, its character and its range, is primarily closely related to lifestyle and the wealth of travellers' landscapes. The rising wealth of many countries that until recently, was falling into the category of developing or backward, clearly illustrates this bond.

In these countries, typical signs are the prolonged life expectancy because of better quality of health-care, more free time thanks to modern 'achievements', globalization and internationalization affecting cultural behaviour of people shorter working time, or better transport infrastructure. However, these areas are already the subject of further investigation.

\section{References}

Ajitabh, A. (2008). Global Competitiveness. New Delhi: Excel Books. ISBN 978-8174466082.

Buhalis, D. (2001). Tourism in Greece: strategic analysis and challenges. Current Issues in Tourism, $4(5), 440-480$.

Djogo, M., \& Stanisic, N. (2016). Is the Global Competitiveness Report the right measure of macroeconomic competitiveness? In Zbornik radova Ekonomskog fakulteta u Rijeci, časopis za ekonomsku teoriju i praksu, 34(1), 91-117.

Dupeyras, A., \& MacCallum, N. (2013). Indicators for measuring competitiveness in tourism: A Guidance Document. OECD Tourism Papers, 2013/02, OECD Publishing. DOI: 10.1787/5k47t9q2t923-en.

Hassan, S. S. (2000). Determinants of Market Competitiveness in an Environmentally Sustainable Tourism Industry. Journal of Travel Research, 38, 239-245.

Hvizdová, E. (2017). New Challenges for Sustainable Tourism. In Current trends and challenges in economics and management (pp. 106-112). Ružomberok: VERBUM. ISBN 978-80-561-0440-8.

Hvizdová, E. (2018). Religious tourism and its socio-economic dimensions. European Journal of Science and Theology, 14(2), 89-98.

Hvizdová, E., \& Radvanská, K. (2014). Slovakia-the country of cultural monuments. Гуманітарний вісник Запорізької державної інженерної академії, (56), 266-275.

Karahuta, M., Gallo, P., Matušíková, D., Šenková, A., \& Šambronská, K. (2017). Forecast of using neural networks in the tourism sector. In CBU International Conference Proceedings (vol. 5, p. 218). Central Bohemia University.

Kozak, M., \& Rimmington, M. (1998). Measuring tourist destination competitiveness: conceptual considerations and empirical findings. International Journal of Hospitality Management, 18 (3), 273-283. DOI: 10.1016/S0278-4319(99)00034-1.

Kravcakova-Vozarova, I., Kotulic, R., \& Sira, E. (2015). V4 countries' agricultural sector evaluation in terms of competitive advantage. Економічний часопис-XXI, 5(6), 60-63.

Kubickova, M. (2016). The Role of Government in Tourism: Linking Competitiveness, Freedom, and Developing Economies. Czech Journal of Tourism, 5(2), 73-92. DOI: 10.1515/cjot-2016-0005.

Liu, C. (2017). International Competitiveness and the Fourth Industrial Revolution. Entrepreneurial Business and Economics Review, 5(4), 111-133. DOI: 10.15678/EBER.2017.050405.

Luštický, M., \& Musil, M. (2016). Towards a Theory of Stakeholders' Perception of Tourism Impacts. Czech Journal of Tourism, 5(2), 93-110. DOI: 10.1515/cjot-2016-0006.

Mira, M. R., Moura, A., \& Breda, Z. (2016). Destination competitiveness and competitiveness indicators: Illustration of the Portuguese reality. Tékhne, 14(2), 90-103. DOI: 10.1016/j.tekhne.2016.06.002. 
Mura, L., \& Ključnikov, A. (2018). Small businesses in rural tourism and agro tourism: study from Slovakia. Economics E Sociology, 11(3), 286-300. DOI: 10.14254/2071-789X.2018/11-3/17.

Navickas, V., \& Malakauskaite, A. (2009). The possibilities for the identification and evaluation of tourism sector competitiveness factors. Engineering Economics, 61(1).

Palatková, M., \& Hrubcová, G. (2015). Monitoring regional competitiveness using the BSC method: A case of the Czech national tourism organisation. Czech Journal of Tourism, 3(2), 107-126. DOI: $10.1515 /$ cjot-2014-0006.

Ritchie, J. R., \& Crouch, G. (2010). A model of destination competitiveness/sustainability: Brazilian perspectives. Revista de Administração Pública, 44(5), 1049-1066.

Šenkova, A., Mitrikova, J., \& Antolikova, S. (2015). Analysis of the selected trends in tourism and hotel industry in the Slovak republic in 1989-2000. Економічний часопис-XXI, 1-2(1), 62-65.

Šambronská, K., Matušíková, D., Šenková, A., \& Mitríková, J. (2016). Comparison of tourism performance in chosen European countries with the accent to Slovak Republic in the period before and after accession to European Union membership at the beginning of 21st century. Ecoforum Journal, 5(1).

Tej, J., \& Matušikova, D. (2014). Tourism product creation as a basis of economic prosperity of a destination. Економічний часопис-XXI, 5(6), 45-48.

Vengesayi, S. (2013). A conceptual model of tourism destination competitiveness and attractiveness. In ANZMAC 2003 Conference Proceedings Adelaide, 637-647.

Vida, M., Kádar, G., \& Kadárová, J. (2017). Analýza konkurencieschopnosti slovenských podnikov (Analyses of the Competitiveness of Slovak Republic Enterprises). Transfer inovácii (Transfer of Innovations), 13/2009, 133-136.

World Economic Forum. (2017). Annual Report TTCR 2017. Retrieved from https://www.weforum.org/reports/the-travel-tourism-competitiveness-report-2017.

Widawski, K. (2017). Spa and Wellness Tourism in Poland-A New Geographical Analysis. Czech Journal of Tourism, 6(1), 69-92. DOI: 10.1515/cjot-2017-0004.

Wilde, S. J., \& Cox, C. (2008). Linking destination competitiveness and destination development: findings from a mature Australian tourism destination. Proceedings of the Travel and Tourism Research Association (TTRA) European Chapter Conference - Competition in tourism: business and destination perspectives, Helsinki, Finland, TTRA, 467-478. 